\title{
EVALUATING PERFORMANCE PROGRESSION IN BEGINNER WHEELCHAIR RUGBY
}

\author{
Judith Berzen", Yeshayahu "Shayke" Hutzler"*
}

\author{
* Israel Sport Center for the Disabled, Israel \\ *:* Zinam College for Physical Education and Sport Science
}

\begin{abstract}
The purpose of this study was to describe the change in selected fitness and skill components over a nine-month period of a new intensive Wheelchair Rugby (WR) practice program. Sixteen WR players of the newly established national league participated in this intervention, which included team and individual practice sessions. Five items of the Beck Battery of Quad Rugby Skills and a 10-min wheelchair push test were performed at the beginning ( $\mathrm{t} 1)$, after three months $(\mathrm{t} 2)$, and after an additional six months period of practice $(\mathrm{t} 3)$. Based on repeated measures t-tests for mean data of at least $50 \%$ of the participants, significant improvements were found in the 10 -min and in the sprint tests between $\mathrm{t} 1$ and $\mathrm{t} 2$, and in the picking and manoeuvrability tests between $\mathrm{t} 2$ and $\mathrm{t} 3$. It can be concluded that this training program was effective in improving players' endurance and manoeuvrability. The application of the test battery for training design and progression control appears very useful.
\end{abstract}

KEYWORDS: training; functional assessment; test; endurance; strength; maneuverability; spinal cord injury

\section{INTRODUCTION}

Wheelchair Rugby (WR), previously called Murder ball and Quad Rugby, is one of the most recent developments in Paralympic sports. It is a team sport for male and female persons with a disability in both their lower and upper limbs, primarily due to spinal cord injury (SCI). In the recent years more and more athletes with other disabilities affecting all four limbs have joined WR teams. WR was invented in 1977 in Winnipeg, Canada by athletes with cervical SCI, and combines elements of basketball, handball, and ice hockey (International Wheelchair Rugby Federation, 2010a). The object of the game is to carry the ball across the opposing teams' goal line, while demonstrating firm control of the ball. WR is played by two teams composed of four players each on a basketball court. It is an equal access, co-gender sport, and therefore females are playing together with males at the same teams. Internationally WR is governed by the International Wheelchair Rugby Federation, (IWRF, 2010b), who determined that the total number of points of all four athletes actually playing on court at any time cannot exceed 8.0 classification points (IWRF, 2010b). Since 1991, a functional classification system has been used to qualify athletes for the game, with seven classes of 0.5 through 3.5 points, accommodating the growing number of athletes both with spinal cord injury and without (such as polio, cerebral palsy, muscular dystrophy, multiple sclerosis and amputations) (IWRF, 2008). Athletes in the higher classes, or "minimal" disability, who are eligible for the sport of WR are more functional and usually play offensive roles, while those in the lower classes typically play defensive roles that require different wheelchairs. Since the Sydney Paralympics in 2000, WR has acquired a full medal status at summer Paralympic Games (2010a). According to the World Ranking List, effective November 9, 2009, 24 teams are ranked and 10 are recognized as representing developing countries (IWRF, 2009), one of which is Israel, where this game has been under development since mid 2009. 


\section{Conditioning Requirements in Wheelchair Rugby}

Wheelchair Rugby is an intermittent type of sport game, with many skilled activities that share similar tasks as in wheelchair basketball (e.g., wheelchair propulsion, manoeuvring, dribbling, passing, and blocking). However, due to the upper limb involvement the patterns of these skills are different than in basketball. Also, WR is more aggressive than wheelchair basketball, and players are allowed to collide in each other. Players are allowed ten seconds with the ball while pushing the wheelchair, before having to pass or dribble. Therefore this pattern of up to 10 seconds of pushing characterizes most of the repetitive powerful actions required on court. The pushes are often asymmetrical due to the need to escape from offensive blocking, and require a high degree of explosive strength and anaerobic fitness. In addition, the accumulated effort during the period played usually challenges aerobic fitness (Morgulec, Kosmol, Molik, Huber-Wozniak, \& Butkowska, 2006). A medium significant correlation $(r=.72, p<.05)$ found between mean power output and $\mathrm{VO}_{2 \text { peak }}$ of WR players in an armcranking sprint test (Goosey Tolfrey, Castle, \& Webborn, 2006) demonstrates the relationship of aerobic and anaerobic performance in WR.

Yilla and Sherrill (1998) constructed and validated a specific WR skill test labelled the "Beck Battery of Quad Rugby Skill Tests". This battery included five tests dedicated to the measurement of performance variables (labelled as skills) typical for WR, including sprinting, manoeuvrability with the ball, picking, passing for distance, and passing for accuracy. After analyzing the data of 65 participants using an oblique rotation, a twofactor solution was revealed, with one factor comprised of manoeuvrability, sprinting, and passing for distance, and the other factor of passing for distance, passing for accuracy, and picking. Nevertheless, it should be noticed that both factors included components of wheelchair as well as ball handling. Both factors explained $66 \%$ of the total variance. Factor loading for manoeuvrability with the ball $(r=.99)$ was highest of the five items, and the authors recommended that this should be the test of choice for assessing players' performance. This test, together with sprinting and picking, were included in a study examining the relationship of these tests with an anaerobic arm ergometry test (Morgulec \& Kosmol, 2007; Morgulec-Adamovicz, Kosmol, \& Molik, 2010). Good correlations ranging between $\mathrm{r}=.60$ to .84 were established, suggesting that these field tests lasting $6-100 \mathrm{sec}$ were strongly related to anaerobic performance. In addition, the effects of one year of training on aerobic performance in arm cranking have been reported, describing a significant increase in all measured variables, including $\mathrm{VE}_{\text {peak }}$; $\mathrm{VO}_{2 \text { peak }}$; and test time (Morgulec et al., 2006). However, until now the sensitivity of fitness performance variables measured in the field to training intervention has not been established. The purpose of this study was to describe the change measured in selected fitness and skill components over a nine-month period of an intensive WR training intervention. A secondary purpose was to establish the factor structure, internal consistency, and validity of the modified test battery.

\section{Method \\ Participants}

Participants in this study were $16 \mathrm{WR}$ players who comprised the teams playing in the first season of the newly-established Israeli league. Participants' age ranged from 14 years to 38 years of age (Mean $=26.3, \mathrm{SD}$ $=6.8$ years $)$. Of the 16 players, 12 had a spinal cord injury (SCI), two had congenital L-Chad non-progressive muscular dystrophy, one had Charcot Marie Tooth hereditary motor and sensory neuropathy, and one had polio. For the participants with SCI, the number of years since injury ranged from one to 18 years $($ Mean $=6.8, \mathrm{SD}=5.9$ years). Fifteen players were male and one was a female. In the absence of an official international classification, the players' classification was estimated before performing the tests based on the assessment of two experts (a coach and an international 
wheelchair sport scholar) who had read the classification manual (6). The sample included a variety of estimated classifications between 0.5 and 3 points. No 3.5 point assessments were reported in this sample..

Table 1 presents the individual data - Personal data of participants in the study

\begin{tabular}{|c|c|c|c|c|c|c|}
\hline \# & Age & Condition & $\begin{array}{c}\text { Years in } \\
\text { WC** }\end{array}$ & Class* & Previous Sport & $\begin{array}{l}\text { Other } \\
\text { Sports }\end{array}$ \\
\hline 1 & 21 & $\mathrm{C} 6$ & 3 & 2 & Basketball & \\
\hline 2 & 38 & C 7-8 & 18 & 2.5 & Basketball & TT; Fitness; Swimming \\
\hline $3 * * *$ & 20 & C 6-7 & 2 & 2 & & \\
\hline $4^{x \times \times}$ & 35 & $\mathrm{C} 6$ & 15 & 1 & Handball & \\
\hline 5 & 14 & MD & & 2.5 & & TT; WBB; Shooting \\
\hline 6 & 24 & C $5-7$ & 4 & 0.5 & & TT \\
\hline 7 & 31 & C 7 & 4 & 3 & & Handcycling \\
\hline 8 & 35 & C 6-7 & 13 & 2 & $\begin{array}{l}\text { Basketball; } \\
\text { Cycling }\end{array}$ & \\
\hline 9 & 30 & C 6-7 & 3 & 2 & & \\
\hline 10 & 26.5 & C 6-7 & 13 & 1.5 & & \\
\hline 11 & 21.5 & C $5-6$ & 2 & 0.5 & & \\
\hline 12 & 21 & C6 & 1 & 2 & Running & \\
\hline 13 & 33 & C 5 & 9 & 2 & Rugby & \\
\hline 14 & 24 & PMD & & 3 & & WBB; TT; Swimming \\
\hline 15 & 26 & PMD & & 2 & & Fitness; Boccia \\
\hline 16 & 20 & C6 & 2 & 1 & Soccer & \\
\hline Mean & 26.3 & & 6.8 & & & \\
\hline STD & 6.8 & & 5.9 & & & \\
\hline
\end{tabular}

* Estimated, ** Including part-time use, *** Player 4 was a female

WC=Wheelchair, TT=Table tenni, WBB=Wheelchair basketball, $P M D=$ Progressive muscular dystrophy

\section{Instrumentation}

In order to assess the fitness components, a selection of tests that were taken from the Beck Battery of Quad Rugby Skills (Yilla \& Sherrill, 1998) was carried out either in the original or a slightly modified version, including: (a) the 20 Meter Sprint Test; (b) the Picking Skill Test; (c) an adapted Pass for Accuracy Test; (d) the Pass for Distance Skill Test; and (e) an adapted Manoeuvrability with Ball Test. Several tests were adapted for ease of use and in order to allow for development of skills, as recommended by Yilla and Sherrill (1998). Based on preliminary experimentations our players, who were beginners, had difficulties to cope with the structure of the pass for accuracy test. Therefore, it was modified in the shape of the target (see Figure 1) compared to the original circular shape, and the number of scores (up to 9 rather than 10 points). For the similar purpose, the manoeuvrability test was also modified from the original. The modified manoeuvrability test was carried out as follows: Players performed slalom in and out of cone gates (Five 3-m and four 2-m gates) positioned in a row, from one end of the course to the other, while maintaining a legal dribble of 10 seconds. If the ball was dropped the player got a zero for that trial, unless he or she was able to retrieve the ball and continue from the point it was dropped (no assistance was allowed). The time was recorded when the player crossed the end line. Two trials were given to each player. In addition, a 10min test for maximal distance was performed to provide a measure of endurance. The five Beck tests were performed in one training session and the 10-min test in another session during the same week. 
Figure 1. Description of Throwing for Accuracy test setting

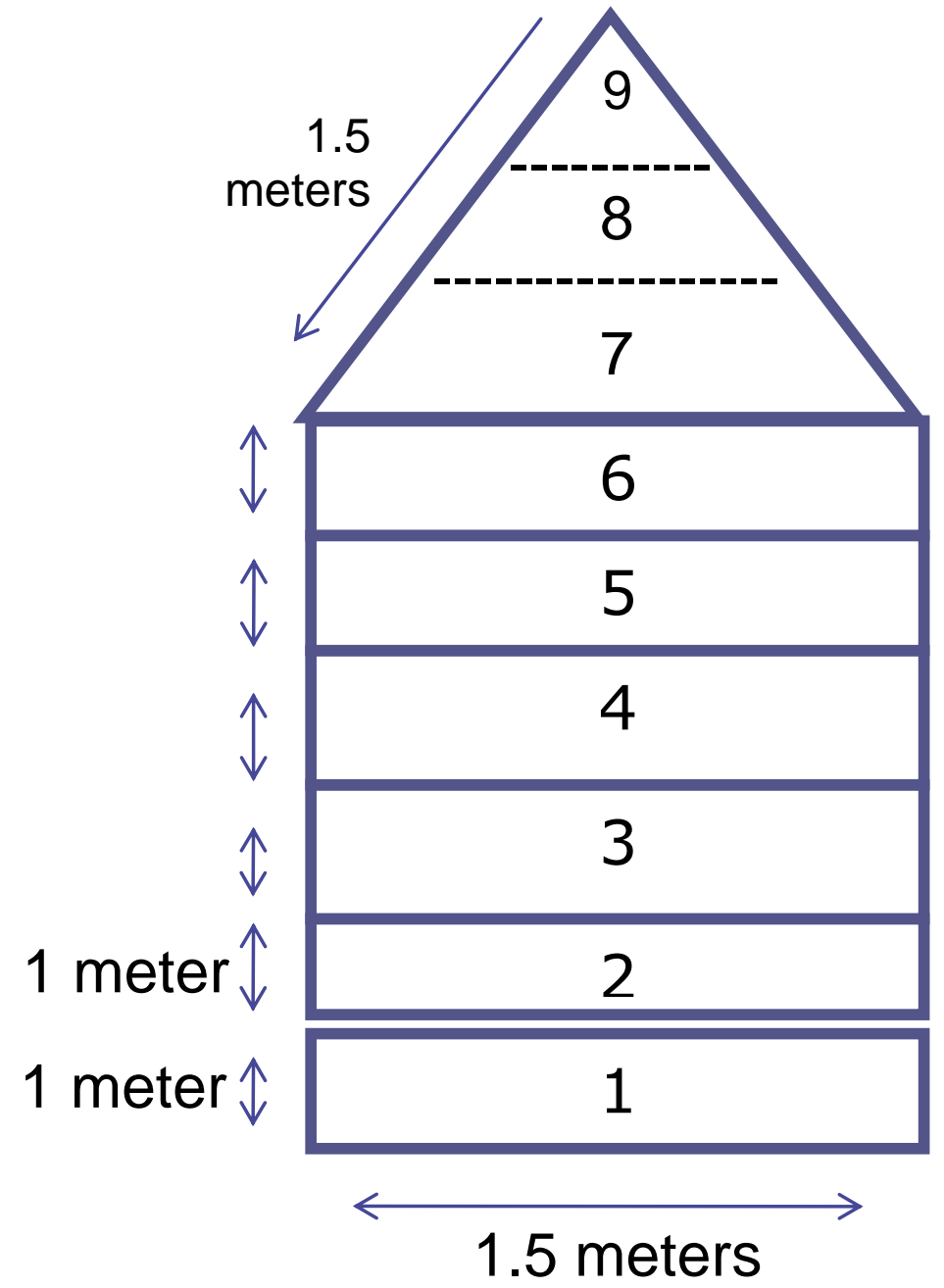

\section{Procedure}

Approval of the study was guaranteed by the Ethical Review Board of the Israel Sport Center for the Disabled. Participation in it was a part of the regular training schedule. Prior to evaluation, testing for a medical clearance for athletes was performed by means of physical examination and ECG measurement undertaken during an arm crank graded ergometer test by a medical practitioner. In addition, all athletes underwent an echocardiogram evaluation by their own health care organization. The first set of endurance and skill testing (t1) was done in August 2009, three months after innitiating to train. The second set $(\mathrm{t} 2)$ was conducted after a three-month period in November 2009, and the third set (t3) after another period lasting six months in May 2010, as the season was over. Not all players were able to attend all three testing sessions, due to illnesses and availability barriers. Between 10 and 14 participants were present at all test times, with the exception of manoeuvrability at $\mathrm{t} 3$ (only 6 athletes).

\section{Training Intervention}

The activity program changed gradually during the progression of the program from predominantly aerobic, strength build-up, and wheelchair propulsion oriented during the first three months of the program (between $\mathrm{t} 1$ and $t 2$ ), to more focused on power in each of the specific WR skills, techniques, and tactics, relative to the competition schedule, which took place during the second half of the period between $\mathrm{t} 2$ and $\mathrm{t} 3$. Throughout the training program participants attended two practice sessions per week lasting about two 
hours each. The training program evolved gradually with aerobic and anaerobic fitness components lasting about $40 \mathrm{~min}$; technical and tactical components lasting about $20 \mathrm{~min}$; and playing another hour. All training units performed at the practices included components similar to those appearing in the example provided in Table 2 .

Table 2. Example for a training plan

\begin{tabular}{|c|c|c|}
\hline Phase & Training components & Duration \\
\hline Warm-up & $\begin{array}{l}\text { Wheelchair propulsion at self-selected } \\
\text { pace }\end{array}$ & $10 \min$ \\
\hline \multirow{4}{*}{$\begin{array}{l}\text { Main part: } \\
\text { Intermittent } \\
\text { Exercise } \\
\text { with aerobic } \\
\text { and } \\
\text { anaerobic } \\
\text { components. }\end{array}$} & $\begin{array}{l}\text { a. Sprints } 6 \text { X } 100 \mathrm{~m} \text { with } 30 \mathrm{sec} \text { rest } \\
\text { periods; }\end{array}$ & $10 \mathrm{~min}$ \\
\hline & $\begin{array}{l}\text { b. Sprints } 6 \text { X } 50 \mathrm{~m} \text { rest } 50 \mathrm{~m} \text { at personal } \\
\text { pace. }\end{array}$ & $10 \mathrm{~min}$ \\
\hline & c. Sprints $8-10 \times 26 \mathrm{~m}$ forward with & $10 \mathrm{~min}$ \\
\hline & $\begin{array}{l}\text { alternated hand pushes, backward and } \\
\text { accelerating from still stand and } \\
\text { breaking }\end{array}$ & $\begin{array}{l}\text { Increasing ratio of short sprints } \\
\text { at the second phase of training }\end{array}$ \\
\hline \multirow{3}{*}{$\begin{array}{l}\text { Main part: } \\
\text { Ball skills }\end{array}$} & a. 100 passes in pairs & $10 \mathrm{~min}$ \\
\hline & b. Bouncing and passing on court & $5 \mathrm{~min}$ \\
\hline & c. Stretching & $5 \min$ \\
\hline \multirow{2}{*}{$\begin{array}{l}\text { Main part: } \\
\text { Game }\end{array}$} & 3-min games $4 \mathrm{X} 4$; every player plays at & $60 \mathrm{~min}$ \\
\hline & $\begin{array}{l}\text { least one session of } 3 \text {-min every second } \\
\text { round. Tactics introduced during game } \\
\text { recessions }\end{array}$ & $\begin{array}{l}\text { Tactics component increased } \\
\text { and increased during second } \\
\text { training phase }\end{array}$ \\
\hline Cool-down & $200 \mathrm{~m}$ wheelchair pushing and stretching & $10 \mathrm{~min}$ \\
\hline
\end{tabular}

\section{Statistical Analysis}

SPSS (version 17; SPSS, Inc., Chicago, IL, USA) was used for the statistical analysis.

Due to the occurrence of missing values, very few tests provided repeated measures of all three test times. Therefore, we performed paired t-test comparisons and Pearson correlations for repeated measures between pairs of times for those participants who were present at both testing times that is, between results of the same participants attending t1 and $\mathrm{t} 2$ and between those attending $\mathrm{t} 2$ and $\mathrm{t} 3$. Bonferroni correction (alpha1 $=\mathrm{alpha} / \mathrm{k}$ ) for multiple comparisons $(\mathrm{k}=2 ; \mathrm{p}=0.025)$ and Cohen's d effect sizes (1988) were used for interpreting the paired comparisons.
Normality of data was analyzed using the histogram method.

In order to assess the test structure, a principal component factor analysis with Varimax rotation was performed on all data points of each test. In addition, a correlation was performed between all data points across the test times for repeatability.

\section{Results}

Table 3 presents comparisons of means and standard deviations (SD), correlations of the repeated measures of participants attending $\mathrm{t} 1$ and $\mathrm{t} 2$ as well as $\mathrm{t} 2$ and $\mathrm{t} 3$, and their effect sizes across tests and times. In addition, change scores between $\mathrm{t} 1$ and $\mathrm{t} 2$ and between $t 2$ and $t 3$ were calculated, and represented as a percent change of the test performed at the previous time (Table 4). 
Table 3 Descriptive, change, and correlation values across tests and times

\begin{tabular}{|c|c|c|c|c|c|c|c|c|c|}
\hline & Test_time & Mean & $\begin{array}{c}\text { Std. } \\
\text { Deviation }\end{array}$ & $\begin{array}{c}\text { Std. } \\
\text { Error } \\
\text { Mean }\end{array}$ & $\begin{array}{c}\% \\
\text { change } \\
\text { of Mean }\end{array}$ & $r$ & $\begin{array}{l}\text { Sig. } \\
\text { of } r\end{array}$ & $\mathrm{~N}$ & $\begin{array}{c}\text { Effect } \\
\text { size }\end{array}$ \\
\hline \multirow[t]{2}{*}{$\begin{array}{l}\text { Pair } 1 \\
(\mathrm{sec})\end{array}$} & $\begin{array}{l}\text { Maneuv } \\
\mathrm{t} 1\end{array}$ & 21.72 & 13.02 & 4.60 & & & & 8 & \\
\hline & $\begin{array}{l}\text { Maneuv } \\
\text { t2 }\end{array}$ & 19.75 & 10.58 & 3.74 & -9.1 & .989 & 0.001 & 8 & 0.17 \\
\hline \multirow[t]{2}{*}{$\begin{array}{l}\text { Pair } 2 \\
(\mathrm{sec})\end{array}$} & $\begin{array}{l}\text { Maneuv } \\
\text { t2 }\end{array}$ & 23.54 & 14.51 & 7.26 & & & & 4 & \\
\hline & $\begin{array}{l}\text { Maneuv } \\
\text { t3 }\end{array}$ & 18.08 & 7.02 & 3.51 & -23.2 & .998 & 0.002 & 4 & 0.48 \\
\hline \multirow[t]{2}{*}{$\begin{array}{l}\text { Pair } 3 \\
\text { (meters) }\end{array}$} & $\begin{array}{l}\text { PassDist } \\
\text { t1 }\end{array}$ & 12.94 & 4.25 & 1.50 & & & & 8 & \\
\hline & $\begin{array}{l}\text { PastDist } \\
\text { t2 }\end{array}$ & 13.25 & 4.61 & 1.63 & 2.4 & .506 & 0.2 & 8 & 0.07 \\
\hline \multirow[t]{2}{*}{$\begin{array}{l}\text { Pair } 4 \\
\text { (meters) }\end{array}$} & $\begin{array}{l}\text { PastDist } \\
\text { t2 }\end{array}$ & 13.19 & 4.60 & 1.63 & & & & 8 & \\
\hline & $\begin{array}{l}\text { PastDist } \\
\text { t3 }\end{array}$ & 13 & 4.97 & 1.76 & -1.4 & .733 & .039 & 8 & 0.04 \\
\hline \multirow{2}{*}{$\begin{array}{l}\text { Pair } 5 \\
\text { (meters) }\end{array}$} & Min10 t1 & 1090.56 & 330.6 & 110.2 & & & & 9 & \\
\hline & $\operatorname{Min} 10$ t2 & 1177.56 & 329.4 & 109.8 & 8.0 & .985 & .000 & 9 & 0.26 \\
\hline \multirow{2}{*}{$\begin{array}{l}\text { Pair } 6 \\
\text { (meters) }\end{array}$} & Min 10 t2 & 1177.4 & 310.6 & 98.2 & & & & 10 & \\
\hline & Min 10 t3 & 1234.8 & 299.7 & 94.8 & 4.9 & .898 & .000 & 10 & 0.19 \\
\hline \multirow{2}{*}{$\begin{array}{l}\text { Pair } 7 \\
(\mathrm{sec})\end{array}$} & Sprint t1 & 10.9 & 6.98 & 2.47 & & & & 8 & \\
\hline & Sprint $\mathrm{t} 2$ & 9.44 & 5.49 & 1.94 & -13.4 & .999 & .000 & 8 & 0.23 \\
\hline \multirow{2}{*}{$\begin{array}{l}\text { Pair } 8 \\
(\mathrm{sec})\end{array}$} & Sprint t2 & 9.30 & 5.13 & 1.71 & & & & 9 & \\
\hline & Sprint $\mathrm{t} 3$ & 8.66 & 2.72 & 0.91 & -7.0 & .969 & .000 & 9 & 0.16 \\
\hline \multirow{2}{*}{$\begin{array}{l}\text { Pair } 9 \\
(\mathrm{sec})\end{array}$} & Picking t1 & 45.17 & 9.93 & 3.75 & & & & 7 & \\
\hline & Picking t 2 & 43.47 & 9.27 & 3.50 & -3.8 & .842 & .017 & 7 & 0.18 \\
\hline \multirow{2}{*}{$\begin{array}{l}\text { Pair } 10 \\
(\mathrm{sec})\end{array}$} & Picking 2 & 50.12 & 20.30 & 7.18 & & & & 8 & \\
\hline & Picking 3 & 40.58 & 12.65 & 4.47 & -19.0 & .975 & .000 & 8 & 0.56 \\
\hline
\end{tabular}

For example, the percent change for pair Manouev1 and Manouev2 presents the percent performance aggregated to the performance in Manouev1. Using the Bonferroni correction for repeated pair comparisons, a significant improvement $(p<.025)$ was found for mean data of at least $50 \%$ (eight cases) of participants in the $10 \mathrm{~min}$ test between $\mathrm{t} 1$ and $\mathrm{t} 2$, and in the picking test between $\mathrm{t} 2$ and $\mathrm{t} 3$.

Also, the manoeuvrability test demonstrated a substantial change $(23.2 \%)$ between $\mathrm{t} 2$ and $\mathrm{t} 3$ (see Table 4). However, it should be noted that only four cases of repeated measures have participated in this test sample, which was apparently not enough for reaching significance or generalizing for the whole 
sample. Medium effect sizes around the 0.5 level (2) were observed only in the picking and manoeuvrability tests between $\mathrm{t} 2$ and $\mathrm{t} 3$.

The principal component factor analysis performed on all data points $(n=48)$ revealed a two factor solution (Eigenvalues > 1), explaining $82.5 \%$ of the variance. The first component explaining 58\% was composed of the three power tests manoeuvrability, sprint and picking (rotated item loadings of .95, .93, and .91 , respectively). The second component with $24.5 \%$ of the variance was composed of the other variables 10-min push, pass for accuracy, and pass for distance $(.86, .70$, and .49 item loadings, respectively). Figure 2 presents the visual distribution of items within the two dimensional rotated space, and demonstrates the strong relationship of the three power items.

Table 4 Paired differences and significance of t-tests performed across tests and time

\begin{tabular}{|c|c|c|c|c|c|c|c|c|c|}
\hline \multirow[b]{3}{*}{ \# } & \multirow[b]{3}{*}{ Test pairs } & \multicolumn{5}{|c|}{ Paired Differences } & \multirow[b]{3}{*}{$\mathrm{t}$} & \multirow[b]{3}{*}{ df } & \multirow{3}{*}{$\begin{array}{l}\text { Sig. (2- } \\
\text { tailed)* }\end{array}$} \\
\hline & & & & \multicolumn{3}{|c|}{$\begin{array}{l}\text { 95\% Confidence Interval of the } \\
\text { Difference }\end{array}$} & & & \\
\hline & & $\begin{array}{l}\text { Nean } \\
\text { change }\end{array}$ & $\begin{array}{l}\text { change } \\
\text { chan }\end{array}$ & $\begin{array}{l}\text { Mean } \\
\text { Mear }\end{array}$ & Lower & Upper & & & \\
\hline Pair 1 & Maneuv t1 - & 1.97 & 3.00 & 1.06 & -0.54 & 4.47 & 1.86 & 7 & .106 \\
\hline Pair 2 & $\begin{array}{l}\text { Maneuv t2 } \\
\text { Maneuv t2 - } \\
\text { Maneuv t3 }\end{array}$ & 5.46 & 7.52 & 3.76 & -6.50 & 17.41 & 1.45 & 3 & .243 \\
\hline Pair 3 & $\begin{array}{l}\text { PassDist } \mathrm{t} 1 \text { - } \\
\text { PassDist } \mathrm{t} 2\end{array}$ & -0.31 & 4.42 & 1.56 & -4.00 & 3.38 & $0 . \overline{20}$ & 7 & .847 \\
\hline Pair 4 & $\begin{array}{l}\text { PassDist t } 2 \text { - } \\
\text { PassDist } \mathrm{t} 3\end{array}$ & 0.19 & 3.51 & 1.24 & -2.75 & 3.13 & 0.15 & 7 & .884 \\
\hline Pair 5 & Min10 t1 - Min10 t2 & -87.00 & 56.59 & 18.86 & -130.50 & -43.50 & $\begin{array}{c}- \\
4.61\end{array}$ & 8 & .002 \\
\hline Pair 6 & Min10 t2 - Min10 t3 & -57.40 & 138.19 & 43.70 & -156.26 & 41.46 & 1.31 & 9 & .222 \\
\hline Pair 7 & Sprint $\mathrm{t} 1$ - Sprint $\mathrm{t} 2$ & 1.46 & 1.51 & 0.53 & 0.19 & 2.72 & 2.73 & 7 & .029 \\
\hline Pair 8 & Sprint $\mathrm{t} 2-$ Sprint $\mathrm{t} 3$ & 0.65 & 2.59 & 0.86 & -1.34 & 2.64 & 0.75 & 8 & .473 \\
\hline Pair 9 & $\begin{array}{l}\text { Picking } \mathrm{t} 1 \text { - Picking } \\
\text { t2 }\end{array}$ & 1.70 & 5.43 & 2.05 & -3.32 & 6.72 & 0.83 & 6 & .439 \\
\hline $\begin{array}{l}\text { Pair } \\
10\end{array}$ & $\begin{array}{l}\text { Picking } \mathrm{t} 2 \text { - Picking } \\
\text { t3 }\end{array}$ & 9.55 & 8.44 & 2.98 & 2.49 & 16.60 & 3.20 & 7 & .015 \\
\hline Pair & PassAcc t1-PassAcc & 7.87 & 11.9 & 4.13 & -1.90 & 17.65 & 1.90 & 7 & .098 \\
\hline 11 & $\mathrm{t} 2$ & & & & & & & & \\
\hline $\begin{array}{l}\text { Pair } \\
12\end{array}$ & $\begin{array}{l}\text { PassAcc t2-PassAcc } \\
\text { t3 }\end{array}$ & -2.22 & 8.93 & 2.98 & -9.08 & 4.64 & 7.47 & 8 & .477 \\
\hline
\end{tabular}

* Due to Bonferroni correction, $(p=0.025)$ was used for the paired comparisons

PassDist = Pass for Distance; Maneuv = Maneuverability; Min 10=10-min; PassAcc = Pass for Accuracy 
Figure 2. Component plot in rotated space depicting factor loadings of tests

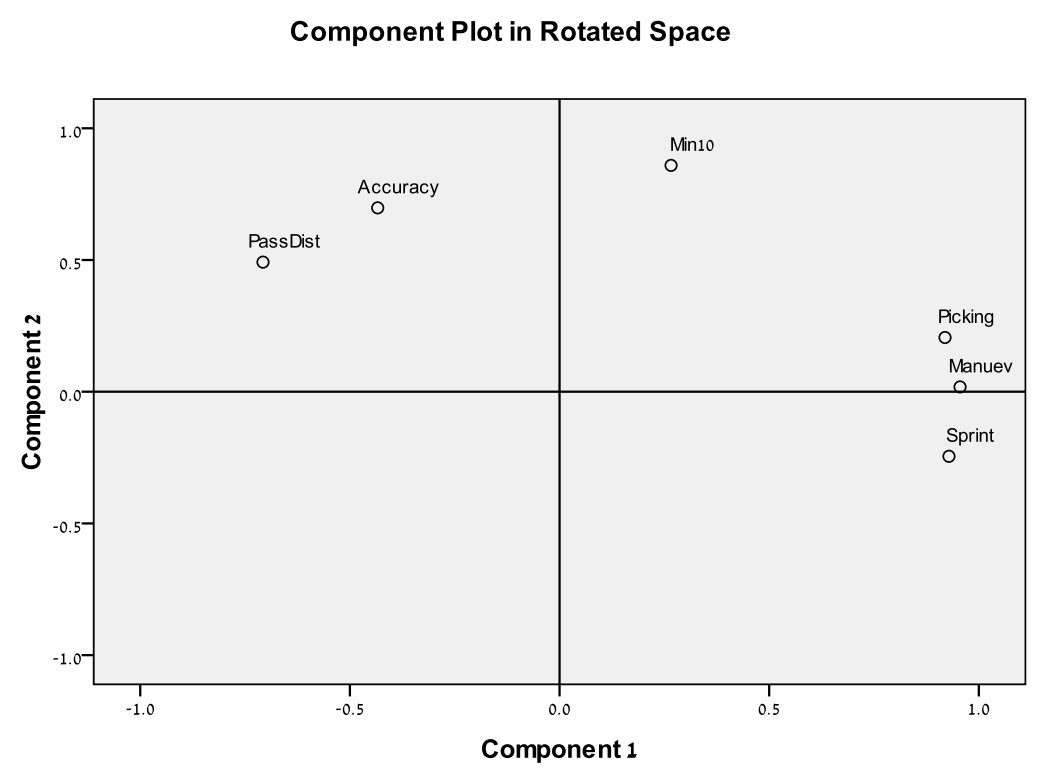

\section{Discussion}

Our analysis of WR players' performance in field tests throughout a 9-month training program provided significant outcomes with regard to the training effects on performance measures, as well as indications of the factorial representation of the test items.

\section{Training outcomes}

A Dutch group (Dallmeijer, Hopman, van As, \& Van der Woude, 1996) evaluated the effect of WR training over a period of six months, on fitness components and physical strain in performing daily activities, such as wheelchair transfers and opening a door. They reported a significant increase in isometric strength and in maximal anaerobic and aerobic performance, and a reduction in physical strain during activities of daily living, due to the WR training. These objective outcomes were reinforced with questionnaire data from New Zealand (Adnan, McKenzie, \& Miyahara, 2001), suggesting an impact on daily activities such as entering and leaving a car, and transferring to and from the wheelchair. In addition, data emerging from a thematic analysis of in-depth interviews with WR players (Goodwin et al., 2009) indicated increased independence experienced through participation in the sport. "I get way more independence by playing rugby then I ever did from a doctor...that's an absolute truth." (Goodwin et al., 2009, p. 110).

Our findings support these previous findings that were conducted with both beginner and expert players. Our outcomes can be partially explained by the content of the training program throughout the period evaluated. Since the first period of three months concentrated more on aerobic and basic strength build-up, and the second period increasingly focused on power and WR skill and tactics training (see Table 2), it makes sense that during the first period the $10 \mathrm{~min}$ test results and in the second period the picking test results improved significantly. In addition, the manoeuvrability test results improved with a medium size effect during the second period. Our findings support previous studies following 6-month (Dallmeijer et al., 1996) and 12-month (Morgulec \& Kosmol, 2007) WR training programs, revealing significant improvement in endurance performance variables of WR players. Our findings are the first to document an improvement in outcomes of the picking and the manoeuvrability tests that can be 
associated with power and agility. Previous results indicate that these tests, together with the sprint test demonstrated medium to strong correlations (range $\mathrm{r}=.60$ to .84) with anaerobic maximal and mean power in an armcranking 30-sec all-out test (MorgulecAdamovicz, Kosmol and Molik, 2010).

Based on armcranking measurements of anaerobic capacity (Morgulec, Kosmol, Vanlandewijck, \& Hubner-Wozniak, 2005), as well as outcomes of self-efficacy evaluations for activities of daily living in WR players compared to non participants with high level spinal cord injury (Adnan et al., 2001), the WR players exhibited significantly higher anaerobic capacity, and reported significantly better self-efficacy in activities requiring power and agility, such as transferring to and from wheelchair to bed, leaving / entering a car, and transferring from seat to wheelchair. These performance variables appear to have an important impact on the well-being in the daily life of WR players. Based on the improvement gained in test performance of our participants after introducing the training program, it may be suggested that this activity could enhance daily life functions. Future studies are encouraged in order to measure the relationships between selected WR and daily life performance measures.

\section{Test structure}

The pooled outcomes of players' performance in the six test items selected provided a robust factorial solution, explaining $82 \%$ of the variance. The six test items were divided into two components, with one of them clearly characterizing power and explosive skills required in WR. Yilla and Sherrill (1998) revealed a similar factor structure for the much larger sample of 65 adult male players, and called this factor manoeuvrability with the ball. They recommended that manoeuvrability should be the test of choice, if players can only be tested on one item. In our sample this test also revealed the highest loading within the test items (.955). Nevertheless, such a practice would omit the ball handling component and therefore should not be advised. The repeatability of the test items across the different testing times was high with correlations for five of the tests ranging between .84 and .99 , and moderate for the pass for accuracy ( $\mathrm{r}$ ranging between .51 and .73).

\section{Limitations}

This was a test of one group of participants, who were at beginner stage of performance. It may not apply to players who are more trained and experienced. In addition, we had a number of missing values that reduced the generalizability of outcomes within our own sample.

\section{Conclusion}

This study revealed significant improvement in WR performance, particularly in the endurance, power, and manoeuvrability-related activities, following a 9-month period of training intervention. The test items used in this study present a potential for future use, but require continuous evaluation of their structure and reliability within studies that include larger samples.

\section{REFERENCES}

Adnan, Y., McKenzie, A., \& Miyahara, M. (2001). Self-efficacy for Quad Rugby skills and activities of daily living. Adapted Physical Activity Quarterly, 18, 90-101.

Cohen, J. (1988). Statistical Power Analysis for the Behavioral Sciences ( $2^{\text {nd }}$ ed.). Mahwah, NJ: Lawrence Erlbaum Associates.

Dallmeijer, A. J., Hopman, M. T., van As, H. H., \& van der Woude, L. H. (. 1996). Physical capacity and physical strain in persons with tetraplegia; the role of sport activity. Spinal Cord, 34, 729-735.

Goodwin, D., Johnston, K., Gustafson, P., Elliot, M., Thurmeier, R., \& Kuttai, H. (2009). It's Okay to be a quad: Wheelchair Rugby players' sense of community. Adapted Physical Activity Quarterly, 26, 102-117. 
Goosey Tolfrey, V., Castle, P., \& Webborn, N. (2006). Aerobic capacity and peak power output of elite quadriplegic games players. British Journal of Sports Medicine, 40, 684-687.

International Wheelchair Rugby Federation, (IWRF) (2008). IWRF classification manual ( $3^{\text {rd }}$ ed.). Retrieved from www.iwrf.com.

International Wheelchair Rugby Federation (IWRF) (2009). Wheelchair rugby world ranking. From www.iwrf.com. Accessed, October $21^{\text {st }}, 2010$.

International Wheelchair Rugby Federation (IWRF) (2010a). About Wheelchair Rugby: General information. From www.iwrf.com. Accessed October $21^{\text {st }}$ 2010.

International Wheelchair Rugby Federation (IWRF) (2010b). A Laypersons Guide to Wheelchair Rugby Classification. From www.iwrf.com. Accessed October $21^{\text {st }}$ 2010.

Morgulec N., \& Kosmol A., (2007):

Aktywność fizyczna w procesie usprawniania osób z uszkodzeniem rdzenia kręgowego w odcinku szyjnym. [Physical activity in the rehabilitation process of individuals with spinal cord injuries in the cervical segments], Warszawa AWF.

Morgulec, N., Kosmol, A., Molik, B., Hubner-Wozniak, E., \& Rutkowska, I. (2006). The effect of training on aerobic performance in wheelchair rugby players. Medsportpress, 12, 195-198.

Morgulec, N., Kosmol, A., Vanlandewijck, Y., \& Hubner-Wozniak, E. (2005):

Anaerobic Performance of Active and Sedentary Male Individuals with Quadriplegia. Adapted Physical Activity Quarterly, 22, 253-264.

Morgulec-Adamovicz, N., Kosmol, A., \& Molik, B. (2010). Enhancing practice in wheelchair sports through research: The example of Wheelchair Rugby in Poland. Abstracts of the Wingate Congress of Exercise and Sport Sciences, June 3-6 2010, pp 24-26.

Yilla, A.B., \& Sherrill, C. (1998). Validating the Beck Battery of quad rugby skill tests. Adapted Physical Activity Quarterly, 15, 155-167.

Corresponding author's e-mail address: shayke@wincol.ac.il

\title{
ANFÄNGERN Judith Berzen", Yeshayahu "Shayke" Hutzler"*
}

BEURTEILUNG DES LEISTUNGSFORTSCHRITTS VON ROLLSTUHL-RUGBY

\author{
* Israel Sport Center for the Disabled, Israel \\ **: Zinam College for Physical Education and Sport Science
}

Die Absicht dieser Untersuchung war es, Veränderungen von ausgewählten Fitness- und Fertigkeitskomponenten eines neuen intensiven Rollstuhl-Rugby(RR)-Trainingsprogramms innerhalb einer neunmonatigen Periode zu beschreiben. Sechzehn RR-Spieler der neu etablierten nationalen Liga nahmen an diesem Interventionsprogramm teil, das Team- und IndividualPraxiseinheiten umfasste. Fünf Testteile der „Beck Battery of Quad Rugby Skills“ und ein 10Minuten Rollstuhl-Antreibe-Test wurden zu Beginn (t 1), nach drei Monaten (t 2) und nach einer weiteren sechsmonatigen Trainingsperiode (t 3) absolviert. Auf der Grundlage von wiederholten tTest-Messungen der Durchschnittswerte von mindestens $50 \%$ der Teilnehmer wurden signifikante Verbesserungen im 10-Minuten Test und den Sprint-Tests zwischen $\mathrm{t} 1$ und $\mathrm{t} 2$ sowie in den „Picking- und Manövrierfähigkeitstests zwischen t 2 und t 3 gefunden. Aus diesen Ergebnissen kann gefolgert werden, dass dieses Trainingsprogramm für die Verbesserung der Ausdauer und der 
Manövrierfähigkeit der Spieler effektiv war. Die Anwendung der Testbatterie erscheint für die Trainingsgestaltung und die Fortschrittskontrolle sehr nützlich.

SCHLÜSSELWÖRTER: Training; funktionelle Beurteilung; Test; Ausdauer; Kraft; Manövrierfähigkeit; Rückenmarksschädigung

\section{(Аннотацця) \\ ОЦЕНКА ЭФФЕКТИВНОСТИ ПРОГРЕССИИ НАЧИНАЮЩИХ ИГРОКОВ РЕГБИ НА ИНВАЛИДНОМ КРЕСЛЕ Джудит Берзен *, Йешаягу "Shayke" Хатслер ** \\ * Israel Sport Center for the Disabled, Israel \\ ** Zinam College for Physical Education and Sport Science}

Целью данной статьи является описание изменений уровня физической подготовленности и навыков игры в регби, которые фиксировались по отдельным нормативам на протяжении девятимесячного курса подготовки спортсменов-инвалидов (на инвалидном кресле). Шестнадцать игроков созданной национальной лиги приняли участие в исследовании, которое включало командный и индивидуальный зачеты. Были проведены испытания по пяти нормативам и 10-минутный тест . в начале курса (T1), по истечению трех месяцев (Т2) и после шести месяцев программы тренировки. В результате исследования были отмечены значительные улучшения у $50 \%$ участников результатов 10 -минутного теста и спринта между Т1 и Т2, а также в тесте на маневренность и быстроту между Т2 и Т3. Можно сделать вывод, что данная программа тренировки является эффективной в развитии выносливости и маневренности спортсменов-инвалидов. Применение данного теста для проектирования и подготовки контроля прогресса оказывается очень полезным.

КЛЮЧЕВЫЕ СЛОВА: обучение, функииональная оченка, тест, выносливость, сила, маневренность, травмы спинного мозга

\section{(Resumen) \\ EVALUACIÓN DE LA PROGRESIÓN EN EL RENDIMIENTO EN EL RUGBY EN SILLA DE RUEDAS DE INICIACIÓN Judith Berzen", Yeshayahu "Shayke" Hutzler"* \\ * Israel Sport Center for the Disabled, Israel \\ ** Zinam College for Physical Education and Sport Science}

El propósito de este estudio fue describir el cambio en la condición física y los determinados componentes de habilidad en un período de nueve meses de un nuevo programa de prácticas intensivo de Rugby en silla de ruedas (WR). Dieciséis jugadores de WR de la recién creada Liga Nacional participaron en esta intervención, que incluía sesiones individuales y de equipo de práctica. Cinco elementos de la batería de habilidades Beck de Quad Rugby, y una prueba de propulsión de 10 minutos en silla de ruedas se realizaron al inicio ( $\mathrm{t} 1$ ), después de tres meses (T 2), y después de un período adicional de seis meses de la práctica (T 3). Usando un test $\mathrm{t}$ de medidas repetidas pruebas $\mathrm{t}$ para datos de la media de al menos el 50\% de los participantes, se observan mejoras significativas en la prueba de 10 minutos y en las pruebas de sprint entre T1 y T2, y en las 
pruebas de bloqueos y capacidad de maniobra entre t 2 y t 3 . Se puede concluir que este programa de entrenamiento fue efectivo en la mejora de la resistencia de los jugadores y la maniobrabilidad. La aplicación de la batería de pruebas se muestra muy útil para el diseño del entrenamiento y el control de la progresión.

PALABRAS CLAVE: entrenamiento, evaluación funcional, prueba; resistencia, fuerza, maniobrabilidad, lesión medular.

\section{AVALIANDO A PROGRESSÃO DA PERFORMANCE EM PRATICANTES INICIANTES DE RUGBY EM CADEIRA DE RODAS Judith Berzen", Yeshayahu "Shayke" Hutzler"* \\ * Israel Sport Center for the Disabled, Israel \\ *** Zinam College for Physical Education and Sport Science}

O objective do presente estudo foi descrever as modificações na condição física e nos componentes dos skills desportivos ao longo de um período de nove meses, de um novo programa intensivo de treino de Rugby em Cadeira de Rodas (RCR). Dezasseis jogadores de RCR participantes no recémcriado campeonato nacional participaram nesta intervenção, a qual incluiu sessões de treino individuais e de grupo. Cinco itens do Beck Battery of Quad Rugby Skills e um teste de 10-min de propulsão em cadeira de rodas foi realizado no início (t 1), três meses após (t 2), e depois de um período adicional de treino com a duração de seis meses ( $\mathrm{t} 3$ ). Tendo por base a realização de um $\mathrm{t}$ teste de medidas repetidas para a comparação de médias de pelo menos $50 \%$ dos participantes, foram encontradas melhorias significativas no teste dos 10 -min e no teste dos sprints entre t1 e t2, e nos testes de escolha e de manobrabilidade entre T 2 e $\mathrm{T} 3$. Pode-se concluir que este programa de treino foi efectivo na melhoria da endurance e da manobrabilidade dos atletas. A aplicação da bateria de testes no contexto do treino e no controlo da progressão dos atletas revelou-se muito útil.

PALAVRAS-CHAVE: treino; avaliação funcional; teste; endurance; força; manobrabilidade; lesão vertebro-medular 